\title{
ANALISIS PENGARUH KUALITAS LAYANAN TERHADAP LOYALITAS PELANGGAN PADA PT SERASI AUTORAYA (TRAC) SEMARANG
}

\author{
Rudi kusnadi $^{1)}$, Agustinus Fritz Wijaya $^{2)}$, dan Penidas Fiodinggo Tanaem ${ }^{3)}$ \\ ${ }^{1,2,3}$ Fakultas Teknologi Informasi, Universitas Kristen Satya Wacana \\ Jl. Notohamidjojo no.1, Salatiga, 50711 \\ E-mail : rudikusnadi97@gmail.com ${ }^{1)}$, agustinus.wijaya@uksw.edu ${ }^{2)}$, fiodinggo@gmail.com ${ }^{3)}$
}

\begin{abstract}
ABSTRAK
Peralatan transportasi telah menjadi salah satu prioritas masyarakat dalam melaksanakan setiap kegiatan perjalanan, baik individu maupun kelompok, sehingga TRAC telah memperhatikan kualitas layanan untuk terus meningkatkan loyalitas pelanggan terhadap layanan, tujuan dari penelitian ini adalah untuk mengevaluasi pengaruh kualitas pelayanan terhadap loyalitas palanggan di PT. Serasi Autoraya . Pendekatan yang digunakan dalam penelitian ini adalah deskriptif kuantitatif, dan sampel yang digunakan adalah random sampling dengan metode analisis regresi linier berganda dengan kuesioner yang dibagikan kepada 50 responden dengan karakteristik responden aktif sewa lebih dari atau sama dengan 6 bulan. Ada 5 variabel untuk menilai kualitas layanan dalam penelitian ini, yaitu x1 (bukti fisik), x2 (keandalan), x3 (responsif), x4 (jaminan) dan x5 (empati).
\end{abstract}

Kata kunci: Kualitas Layanan, Loyalitas Pelanggan, Regresi Linier Berganda

\section{PENDAHULUAN}

Alat transportasi telah menjadi salah satu prioritas masyarakat dalam melakukan setiap aktivitas perjalanan baik itu individu maupun kelompok. Dalam beberapa tahun terakhir, telah berkembang sistem persewaan alat transportasi, dimana didalam sistem tersebut pelanggan datang ke rental atau stasiun persewaan, memanfaatkan kendaraan untuk beberapa waktu, dan kemudian mengembalikan kendaraan ke stasiun yang mereka pilih (George and Xia, 2011). Pertumbuhan sistem persewaan kendaran memiliki potensi pertumbuhan. Sebagimana yang dilaporkan oleh Before It's News, bahwa industry persewaan diperkirakan akan mencapai nilai US \$67,6 miliar pada 2017, dengan compound annual growth rate (CAGR) 3,5\% selama lima tahun ke depan (Zakaria et al., 2014). Terdapat beberapa indikator yang sering menjadi perhatian dalam persewaan alat transportasi yang ada. Indikator tersebut antara lain kondisi fisik dan administrasi kerdaraan. Banyaknya jumlah jasa rental yang ada saat ini membuat persaingan menjadi semakin ketat, baik dalam meningkatkan jumlah pelanggan maupun mempertahankan pelanggan yang telah ada. Perusahaan-perusahaan jasa rental berusaha untuk bertahan dalam persaingan pasar melalui penawaran produk dan pelayanan dengan keunggulan masing-masing. Kualitas pelayanan yang optimal dapat dijadikan sebagai salah satu strategi perusahaan untuk meningkatkan serta mempertahankan pelanggan. Kualitas pelayanan yang optimal diharapkan akan mampu memenuhi harapan pelanggan sehingga akan menciptakan kepuasan dan loyalitas perusahaan. Pelanggan yang loyal merupakan aset berharga untuk menjaga kelangsungan hidup perusahaan dalam persaingan pasar yang ketat. Sebagai respon terhadap kondisi tersebut, maka para penyedia layanan transportasi berusaha untuk memenuhi setiap indicator yang terus menjadi prioritas para pengguna.

PT. Serasi Autoraya adalah perusahaan yang bergerak dibidang peyedia layanan transportasi yang berada di kota semarang. PT. Serasi Autoraya terus berusaha untuk menyediakan layanan yang mampu menjawab semua kebutuhan pelanggannya demi menjaga kepercayaan serta loyalitas pelanggan akan setiap layanan yang menjadi nilai tawar mereka. Dengan demikian perlu untuk dilakukan evaluasi terhadap pengaruh kualitas pelayanan tehadap loyalitas pelanggan. Alasan dilakukannya evaluasi tersebut karena: loyalitas pelanggan sering kali berubah seiring berjalannya waktu karena berbagai alasan.

Disisilain, TRAC juga telah memperhatikan kualitas pelayanan untuk terus meningkatkan loyalitas pelanggan terhadap pelayanan dengan sistem dan teknologi yang ada, hubungan TRAC dengan sistem dan teknologi yang ada sangat begitu erat, terutama Sistem informasi dan tekologi informasi yang diterapkan dalam administrasi layanan TRAC sangat berperan penting untuk mencapai keberhasilan proses dan tujuan perusahaan. dengan adanya sistem informasi terutama SAP (System Application and Product in data processing) TRAC telah mempermudah proses pencapaian kualitas pelayan untuk mendapatkan loyalitas pelanggan dan TRAC juga menerapkan sebuah teknologi yang dapat mengatur administrasi sistem 
pemerintahan bawaslu dalam proses pemesanan jasa layanan TRAC diluar sistem administrasi (SPAMKODOK) dengan begitu sistem informasi dan teknologi informasi dapat digunkan dalam menentukan kualitas pelayanan dan loyalitas pelanggan. Dari pengertian diatas dapat diartikan bahwa peran kualitas pelayanan merupakan hal yang sangat penting dan berpengaruh. Alasan yang mendasari pemilihan objek penelitian ini karena PT. SERASI AUTORAYA merupakan salah satu perusahaan yang menawarkan jasa pelayanan yang berkualitas dengan mengutamakan aspek keselamatan dan keamanan. Mengacu pada kondisi tersebut,maka penting untuk dilakukan penelitan terkait "ANALISIS PENGARUH KUALITAS PELAYANAN TERHADAP LOYALITAS PELANGGAN PADA PT SERASI AUTORAYA SEMARANG". Atas dasar uraian permasalahan yang ada maka bertujuan yang ingin dicapai adalah melakukan evaluasi terhadap pengaruh kualitas pelayanan terhadap loyalitas pelanggan di PT. Serasi Autoraya dengan menggunakan pendekatan regresi linear dalam menetukan hasil analisis yang digunakan.

\section{RUANG LINGKUP}

Rumusan masalah dalam penelitian ini adalah apakah Kualitas layanan berpengaruh pada loyalitas pelanggan Hipotesis yang diajukan peneliti yaitu :

1. Kualitas layanan berpengaruh terhadap loyalitas pelanggan

2. Tanggible berpengaruh terhadap loyalitas pelanggan

3. Realibelity berpengaruh terhadap loyalitas pelanggan

4. Responsivess berpengaruh terhadap loyalitas pelanggan

5. Assurance berpengaruh terhadap loyalitas pelanggan

6. Empaty berpengaruh terhadap loyalitas pelanggan

\section{BAHAN DAN METODE}

Berikut disajikan bahan kajian pustaka, metodelogi, tahapan dan hasil yang terkait dengan penelitian ini

\subsection{Kajian Empirik}

Penelitian sebelumnya yang pertama kali dilakukan oleh Firend A. Rasheed, Masoumeh F. Abadi di Malaysia dengan judul "Impact Of Service Quality, Trust And Perceived Value On Customer Loyalty In Malaysia Services Industries" penelitian ini mengunakan penilaian dengan tiga faktor yakni kualitas layanan, kepercayaan dan nilai yang dirasakan oleh pelanggan di industri perbankan, asuransi, dan telekomunikasinya. terdapat hubungan yang positif antara kualitas layanan dan kepercayaan, kualitas layanan dan nilai yang dipersepsikan, kepercayaan dan loyalitas pelanggan dan nilai yang dirasakan pelanggan. Akibatnya, berdasarkan temuan, kualitas layanan, kepercayaan dan nilai yang dirasakan dianggap sebagai anteseden dari loyalitas pelanggan (Rasheed and Abadi,
2014) Penelitian kedua dilakukan di perbankan Yunani oleh Argyrios Kranias, Maria Bourlessa dengan judul "Investigating The Relationship Between Service Quality And Loyalty In Greek Banking Sector" dengan hasil penelitian bahwa pendekatan bank berpengaruh pada loyalitas pelanggan terutama pada kenyaman fasilitas, kompetensi karyawan, kehandalan fisik bukti dan inovasi. Terbukti dari penilaian kualitas tingkat layanan yang dilakukan di delapan bank Yunani mengunakan instrument yang dikembangkan oleh Gounaris et al (Kranias and Bourlessa, 2013).

Selanjutnya penelitian ketiga dilakukan di Fixed-Wire Line Phone surakarta oleh Rizki Fajar Kusumo Putro dengan judul "Pengaruh Kualitas Pelayanan Terhadap Loyalitas Pelanggan Dengan Kepuasan Pelanggan Sebagai Variabel Pemediasi" dengan Tujuan penelitian untuk mengetahui pengaruh signifikan kualitas pelayanan terhadap loyalitas pelanggan, pengaruh signifikan kepuasan pelanggan terhadap loyalitas pelanggan, serta pengaruh kualitas pelayanan terhadap loyalitas pelanggan dengan kepuasan pelanggan sebagai variabel mediasi. Metode yang digunakan metode survey dengan penelitian kasual untuk teknik sampling yang digunakan adalah non probability sampling dengan metode purposive sampling. Sedangakan untuk pengujian pengaruh antara variabel kualitas pelayanan terhadap loyalitas pelanggan dengan melibatkan variabel mediasi kepuasan pelanggan digunakan analisis jalur (path analysis). Dengan hasil penelitian yang didapat bahwa perhitungan path analysis dimana nilai $\beta$ kualitas pelayanan pada kepuasan pelanggan signifikan pada $\mathrm{p}<0,01$, nilai $\beta$ kepuasan pelanggan pada loyalitas pelanggan signifikan pada $\mathrm{p}<0,05$ dan nilai $\beta$ kualitas pelayanan pada loyalitas pelanggan signifikan pada $\mathrm{p}<0,01$, maka secara statistik dapat ditunjukkan bahwa kepuasan pelanggan memediasi pengaruh kualitas pelayanan terhadap loyalitas pelanggan (Fajar Kusumo Putro, 2009).

Perbedaan penelitian ini dengan penelitian terdahulu ialah metode pendekatannya yang mengunakan metode deskriptif kuantitatif, pengambilan sampel dengan random sampling, dan metode analisisnya yang mengunakan analisis regresi linier berganda dengan sampel yang diambil ialah pelanggan aktif yang lebih atau sama dengan 6 bulan pengunaanjasa TRAC.

\subsection{Kualitas Pelayanan}

Pemahaman mengenai kualitas sangat beraneka ragam dan mengandung banyak makna menurut KBBI kualitas diartikan sebagai kadar atau dengan kata lain tingkat buruknya sesuatu (KBBI). Grönroos berpendanpat bahwa kualitas merupakan sebuah teknis mengambarkan bagaimana pelanggan mendapatan fasilitas pelayanan dari sebuah produk yang dijanjikan (Yeo, Thai and Roh, 2015). Selanjutnya Zeithaml, \& Berry kualitas adalah sebuah kata 
yang bagi penyedia jasa merupakan sesuatu yang harus dikerjakan dengan baik. Dimana terdapat variabel yang berpengaruh terhadap loyalitas pelanggan yakni: tangibles, reliability, responsiveness, assurance, empathy. Tangibles (berwujud) merupakan kualitas pelayanan berupa sarana fisik perkantoran, komputerisasi administrasi, ruang tunggu, tempat informasi, Realibility (kehandalan) merupakan kemampuan dan kehandalan untuk menyediakan pelayanan yang terpercaya, Responsivess (ketanggapan) merupakan kesanggupan untuk membantu dan menyediakan pelayanan secara cepat dan tepat, serta tanggap terhadap keinginan konsumen, Assurance (jaminan) merupakan kemampuan dan keramahan serta sopan santun pegawai dalam meyakinkan kepercayaan konsumen, dan Emphaty (Empati) merupakan sikap tegas tetapi penuh perhatian dari pegawai terhadap konsumen (Ariffin, Abdullah and Bibon, 2012).

\subsection{Loyalitas Pelanggan}

Loyalitas adalah kesetian pelanggan untuk kembali mengunakan jasa atau produk kita dengan adanya loyalitas pelanggan itu sendiri dapat menjadi kondisi pasar yang bermodalkan kepercayaan pelanggan terhadap produk semakin besar. Menurut Baran, Galka \& Strunk loyalitas dapat diartikan bahwa situasi dimana pelanggan secara konsisten membelanjakan seluruh anggaran yang dimilikinya untuk membeli produk atau jasa dari penjual secara berulang-ulang (Ariff et al., 2014). Selanjutnya Oliver mengngkapkan bahwa ada beberapa komponen yang dapat digunakan untuk meninjau loyalitas pelanggan (Monjelat et al., 2018), diantaranya: a) Loyalitas kognitif (cognitive loyalty) atau loyalitas yang didasarkan hanya pada keyakinan merek. b) Loyalitas afektif (affective loyalty) atau kesukaan atau sikap terhadap merek didasarkan pada kesempatan menggunakan kepuasan secara kumulatif. c) Loyalitas konatif (conative loyalty) yang menunjukkan sebuah kondisi loyalitas yang berisi apakah pada kemunculan pertama memperlihatkan komitmen mendalam untuk membeli. d) Loyalitas tindakan (action loyalty), di mana niat dikonversi ke tindakan.

\subsection{Karakteristik Responden}

Sampel yang digunakan adalah pelanggan (aktif) yang masih mengunakan jasa trac dengan masa sewa lebih atau sama dengan 6 bulan yang diambil secara random sampling dimana semua individu dalam populasi baik secara sendiri-sendiri atau bersama-sama diberi kesempatan yang sama untuk dipilih sebagai anggota sampel. Dalam penelitian ini mengunakan analisis regresi linier berganda (Ghozali) dengan rumus (Sari, 2014).

$Y=a+b 1 . X 1+b 2 \cdot x 2+b 3 \cdot x 3+b 4 \cdot x 4+b 5 \cdot x 5+e$
Dimana (1) :

Y : Loyalitas Konsumen

a : Konstanta

X1 : Bukti Fisik

$\mathrm{X} 2$ : Kehandalan

$\mathrm{X} 3$ : Ketangapan

$\mathrm{X} 4$ : Asuransi

X5 : Empati

b : Koefisien Regresi

e : Tingkat Kesalahan

\subsection{Tahapan Penelitian}

Adapun tahapan dalam penelitian ini sebagai berikut :

1. Tahap Pendahuluan

Merupakan survey awal untuk mengetahui kondisi perumahan dengan melakukan pengamatan langsung maupun tidak langsung ke perumahan.

1) Identifikasi Masalah

Merupakan bagian dari kegiatan penelitian untuk mendapatkan gambaran tentang atribut yang menjadi permasalahan dan mencari solusi dari permasalahan yang ada.

2) Studi Literatur,

Dalam mengidentifikasi permasalahan dibutuhkan literatur yang berhubungan dengan masalah dari penelitian yang dilakukan. Dengan literatur diharapkan dapat mengetahui teori, konsep dan metode yang mendukung dalam penelitian.

3) Tujuan Penelitian

Setelah mengetahui permasalahan yang telah dirumuskan maka dilanjutkan dengan menuliskan tujuan yang diharapkan dari penelitian ini.

\section{Penentuan Atribut}

Adapun penentuan atribut dalam penelitian ini terdiri dari 5 atribut antara lain:

1) Tangibles (berwujud): kualitas pelayanan berupa sarana fisik perkantoran, komputerisasi administrasi, ruang tunggu, tempat informasi. Indikatornya adalah :

1. Penampilan petugas/aparatur dalam melayani pelanggan

2. Kenyamanan tempat melakukan pelayanan

3. Kemudahan dalam proses pelayanan

4. Kedisiplinan petugas/aparatur dalam melakukan pelayanan

5. Kemudahan akses pelanggan dalam permohonan pelayanan

6. Penggunaan alat bantu dalam pelayanan

2) Realibility (kehandalan): kemampuan dan keandalan untuk menyediakan pelayanan yang terpercaya. Indikatornya adalah :

1. Kecermatan petugas dalam melayani

2. Memiliki standar pelayanan yang jelas 
3. Kemampuan petugas/aparatur dalam menggunakan alat bantu dalam proses pelayanan

3) Responsivess (ketanggapan): kesanggupan untuk membantu dan menyediakan pelayanan secara cepat dan tepat, serta tanggap terhadap keinginan konsumen. Indikatornya adalah:

1. Merespon setiap pelanggan/pemohon yang ingin mendapatkan pelayanan

2. Petugas/aparatur melakukan pelayanan dengan cepat

3. Petugas/aparatur melakukan pelayanan dengan tepat

4. Petugas/aparatur melakukan pelayanan dengan cermat

5. Petugas/aparatur melakukan pelayanan dengan waktu yang tepat

6. Semua keluhan pelanggan direspon oleh petugas

4) Assurance (jaminan): kemampuan dan keramahan serta sopan santun pegawai dalam meyakinkan kepercayaan konsumen. Indikatornya adalah :

1. Petugas memberikan jaminan tepat waktu dalam pelayanan

2. Petugas memberikan jaminan biaya dalam pelayanan

3. Petugas memberikan jaminan legalitas dalam pelayanan

4. Petugas memberikan jaminan kepastian biaya dalam pelayanan

5) Emphaty (Empati): sikap tegas tetapi penuh perhatian dari pegawai terhadap konsumen, indikatornya adalah :

1. Mendahulukan kepentingan pelanggan

2. Petugas melayani dengan sikap ramah

3. Petugas melayani dengan sikap sopan santun

4. Petugas melayani dengan tidak diskriminatif (membeda-bedakan)

5. Petugas melayani dan menghargai setiap pelanggan

3. Penyusunan Kuisioner

Tipe dalam kuesioner ini adalah kuesioner tertutup, sedangkan pengumpulan data kuesioner adalah dengan cara personal yaitu bertemu secara langsung. dalam penyusunan kuesioner ada 5 atribut yang digunakan yakni Tangible (berwujud), Reliabelity (kehandalan), Responsiviness (ketanggapan), Assurance (jaminan) dan Emphaty (Empati) dengan menggunakan skala Likert, Pada kuisioner Skala Likert yang digunakan yaitu $1=$ Sangat tidak baik, 2 = Tidak baik, $3=$ Cukup, $4=$ Baik dan 5 = Sangat Baik

Penentuan ukuran sampel pada penyebaran kuisioner dalam penelitian ini menggunakan persamaan persamaan Bernoulli (distribusi normal), Astra (2010) dalam pendapatnya Ronald E Walpole yang diketahui dengan rumus sebagai berikut:

$$
\mathrm{N} \geq \frac{(\mathrm{Z} \alpha / 2)^{2} \mathrm{p} . \mathrm{q}}{\mathrm{e}^{2}}
$$

Dimana (2):

$\mathrm{N}=$ jumlah sampel minimum

$\alpha=$ tingkat keyakinan

$\mathrm{Z}(\alpha / 2=$ nilai distribusi normal (1.96) $\mathrm{e}=$ tingkat kesalahan

$\mathrm{p}=$ proporsi jumlah kuesioner yang dianggap benar

$q=$ proporsi jumlah kuesioner yang dianggap salah

Kuisoner penelitian merupakan kuisoner tertutup yang akan disebarkan kepada 50 responden yang merupakan pelanggan TRAC. Responden akan diminta untuk memberikan penilaian terhadap pertanyaan yang diajukan sesuai dengan skala likert 1-5.

4. Analisa dan Pembahasan

Berisikan penyusunan secara sistematik dan disertai dengan argumentasi yang memiliki dasar referensi dan data-data valid tentang informasi ilmiah dalam penelitian, terutama informasi yang relevan dengan masalah penelitian.

\section{PEMBAHASAN}

Berdasarkan hasil kuisioner yang dibagikan pada pelanggan, diperoleh hasil sebagai berikut;

1. Variabel tangible (berwujud)

Tanggibles merupakan kualitas pelayanan yang berhubungan dengan sarana-prasarana kantor serta penampilan dari pegawai.

Tabel 1. Tanggibles (X1)

\begin{tabular}{|l|l|l|l|}
\hline No & $\begin{array}{l}\text { Kategori } \\
\text { Jawaban }\end{array}$ & Skor & Frekuensi \\
\hline $\mathbf{1}$ & Sangat Baik & $\mathbf{5}$ & $\mathbf{2 9}$ \\
\hline $\mathbf{2}$ & Baik & $\mathbf{4}$ & $\mathbf{2 0}$ \\
\hline $\mathbf{3}$ & Cukup Baik & $\mathbf{3}$ & $\mathbf{1}$ \\
\hline $\mathbf{4}$ & Tidak Baik & $\mathbf{2}$ & - \\
\hline $\mathbf{5}$ & $\begin{array}{l}\text { Sangat Tidak } \\
\text { Baik }\end{array}$ & $\mathbf{1}$ & - \\
\hline & Total & & $\mathbf{5 0}$ Responden \\
\hline
\end{tabular}

Sumber : data diolah , 2019

Dilihat dari tabel 1 variabel tanggible jawaban responden yang lebih dominan adalah sangat baik.dengan jumlah 29 dari 50 responden. 
2. Variabel Realibelity (kehandalan)

Reabelity merupakan kemampuan untuk memberikan pelayanan yang sesuai dengan janji atau kesepakatan yang ditawarkan kepada customer.

Tabel 2. Reabelity (X2)

\begin{tabular}{|l|l|l|l|}
\hline No & Kategori Jawaban & Skor & Frekuensi \\
\hline $\mathbf{1}$ & Sangat Baik & $\mathbf{5}$ & $\mathbf{1 5}$ \\
\hline $\mathbf{2}$ & Baik & $\mathbf{4}$ & $\mathbf{3 5}$ \\
\hline $\mathbf{3}$ & Cukup Baik & $\mathbf{3}$ & - \\
\hline $\mathbf{4}$ & Tidak Baik & $\mathbf{2}$ & - \\
\hline $\mathbf{5}$ & Sangat Tidak Baik & $\mathbf{1}$ & - \\
\hline & Total & & $\mathbf{5 0}$ Responden \\
\hline
\end{tabular}

Sumber : data diolah , 2019

Dilihat dari tabel 2 variabel reabelity jawaban responden yang lebih dominan adalah baik.dengan jumlah 35 dari 50 responden.

3. Variabel Responsivess (ketanggapan)

Responsivess merupakan respon atau kesigapan karyawan dalam membantu dan memberikan pelayanan yang cepat serta tanggap ketika ada keluhan atau permasalahan.

Tabel 3. Responsivess (X3)

\begin{tabular}{|l|l|l|l|}
\hline No & $\begin{array}{l}\text { Kategori } \\
\text { Jawaban }\end{array}$ & Skor & Frekuensi \\
\hline $\mathbf{1}$ & Sangat Baik & $\mathbf{5}$ & $\mathbf{3 5}$ \\
\hline $\mathbf{2}$ & Baik & $\mathbf{4}$ & $\mathbf{1 5}$ \\
\hline $\mathbf{3}$ & Cukup Baik & $\mathbf{3}$ & - \\
\hline $\mathbf{4}$ & Tidak Baik & $\mathbf{2}$ & - \\
\hline $\mathbf{5}$ & Sangat Tidak Baik & $\mathbf{1}$ & - \\
\hline & Total & & $\mathbf{5 0}$ Responden \\
\hline
\end{tabular}

Sumber : data diolah , 2019

Dilihat dari tabel 3 variabel responsivess jawaban responden yang lebih dominan adalah sangat baik.dengan jumlah 35 dari 50 responden.

\section{Variable Assurance (jaminan)}

Asurance merupakan kemampuan dan keramahan serta sopan santun pegawai dalam meyakinkan kepercayaan konsumen.
Tabel 4 Assurance (X4)

\begin{tabular}{|l|l|l|l|}
\hline No & $\begin{array}{l}\text { Kategori } \\
\text { Jawaban }\end{array}$ & Skor & Frekuensi \\
\hline $\mathbf{1}$ & Sangat Baik & $\mathbf{5}$ & $\mathbf{3 0}$ \\
\hline $\mathbf{2}$ & Baik & $\mathbf{4}$ & $\mathbf{1 5}$ \\
\hline $\mathbf{3}$ & Cukup Baik & $\mathbf{3}$ & $\mathbf{5}$ \\
\hline $\mathbf{4}$ & Tidak Baik & $\mathbf{2}$ & - \\
\hline $\mathbf{5}$ & $\begin{array}{l}\text { Sangat Tidak } \\
\text { Baik }\end{array}$ & $\mathbf{1}$ & - \\
\hline & Total & & $\mathbf{5 0}$ Responden \\
\hline
\end{tabular}

Sumber : data diolah , 2019

Dilihat dari tabel 4 variabel tanggible jawaban responden yang lebih dominan adalah sangat baik.dengan jumlah 30 dari 50 responden.

5. Variable Empathy (empati/simpati)

Empati merupakan perhatian secara individual yang diberikan perusahaan kepada pelanggan serta sikap tegas tetapi penuh perhatian dari pegawai terhadap konsumen.

Tabel 5 Empaty (X5)

\begin{tabular}{|l|l|l|l|}
\hline No & $\begin{array}{l}\text { Kategori } \\
\text { Jawaban }\end{array}$ & Skor & Frekuensi \\
\hline $\mathbf{1}$ & Sangat Baik & $\mathbf{5}$ & $\mathbf{1}$ \\
\hline $\mathbf{2}$ & Baik & $\mathbf{4}$ & $\mathbf{4 3}$ \\
\hline $\mathbf{3}$ & Cukup Baik & $\mathbf{3}$ & $\mathbf{6}$ \\
\hline $\mathbf{4}$ & Tidak Baik & $\mathbf{2}$ & - \\
\hline $\mathbf{5}$ & $\begin{array}{l}\text { Sangat Tidak } \\
\text { Baik }\end{array}$ & $\mathbf{1}$ & - \\
\hline & Total & & $\mathbf{5 0}$ Responden \\
\hline
\end{tabular}

Sumber : data diolah , 2019

Dilihat dari tabel 5 variabel tanggible jawaban responden yang lebih dominan adalah baik.dengan jumlah 43 dari 50 responden.

6. Variabel loyalitas kosumen

Loyalitas konsumen merupakan suatu ukuran kesetiaan dari pelanggan dalam mengunakan suatu merk atau jasa dari brand tersebut dengan kurun waktu tertentu pada situasi dimana banyak pilihan produk yang sama untuk memenuhi kebutuhan pelanggan.

Tabel 6. Loyalitas Pelanggan (Y)

\begin{tabular}{|l|l|l|l|}
\hline No & $\begin{array}{l}\text { Kategori } \\
\text { Jawaban }\end{array}$ & Skor & Frekuensi \\
\hline $\mathbf{1}$ & Sangat Baik & $\mathbf{5}$ & $\mathbf{2 0}$ \\
\hline $\mathbf{2}$ & Baik & $\mathbf{4}$ & $\mathbf{3 0}$ \\
\hline
\end{tabular}




\begin{tabular}{|l|l|l|l|}
\hline $\mathbf{3}$ & Cukup Baik & $\mathbf{3}$ & - \\
\hline $\mathbf{4}$ & Tidak Baik & $\mathbf{2}$ & - \\
\hline $\mathbf{5}$ & Sangat Tidak Baik & $\mathbf{1}$ & - \\
\hline & Total & & $\mathbf{5 0}$ Responden \\
\hline
\end{tabular}

Sumber : data diolah , 2019

Dilihat dari tabel 6 loyalitas pelanggan, jawaban responden yang lebih dominan adalah baik.dengan jumlah 30 dari 50 responden. Analisis statistic regresi linier dilakukan dengan mengunakan SPSS (Statitic Program For Sosial Science) versi 24. Dengan hasil analisis sebagai berikut ;

Tabel 7. Analisis Regresi Linier Berganda

\begin{tabular}{|c|c|c|c|}
\hline \multicolumn{4}{|l|}{ Coefficients $^{a}$} \\
\hline & \multicolumn{2}{|c|}{ Unstandardized } & $\begin{array}{l}\text { Standardize } \\
\text { d }\end{array}$ \\
\hline & \multicolumn{2}{|c|}{ Coefficients } & Coefficients \\
\hline & & & \\
\hline Model & B & Error & Beta \\
\hline 1 (Constant) & 2.268 & 1.561 & \\
\hline tangibles & -.116 & .140 & -.126 \\
\hline reabelity & .359 & .159 & .336 \\
\hline $\begin{array}{l}\text { responsiv } \\
\text { ess }\end{array}$ & .244 & .164 & .228 \\
\hline assurance & -.074 & .116 & -.102 \\
\hline empaty & .077 & .197 & .057 \\
\hline a. Depende & Variak & Loyalit & s pelanggan \\
\hline
\end{tabular}

Dapat dilihat dari tabel di atas dapat diketahui bahwa nilai a (konstanta) adalah 2.268 , nilai $x 1$ adalah $(-0,116)$, nilai $x 2$ adalah 0,359 , nilai $x 3$ adalah 0,244 , nilai $x 4$ adalah 0,074 , dan nilai $x 5$ adalah 0,077 . Sehingga diperoleh persamaan regresi : $\mathrm{Y}=2.268+-0,116 \mathrm{X} 1+0,359 \mathrm{X} 2+$ $0,244 \mathrm{X} 3+-0,074 \mathrm{X} 4+0,071 \mathrm{X} 5$

Besar atau kuatnya hubungan variabel independen terhadap variabel dependen, serta besarnya koefisien determinasi dapat dilihat pada model summary.

Tabel 8. Analisis Korelasi Dan Determinasi

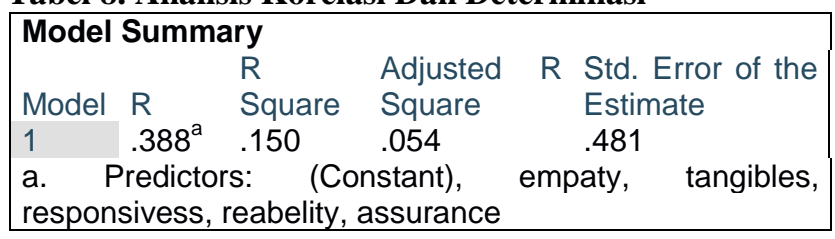

Pengujian hipotesis pertama yaitu kualitas layanan yang terdiri dari keandalan, daya tanggap, jaminan, empati, dan bukti fisik berpengaruh signifikan terhadap loyalitas konsumen
Tabel 9. Analisis Uji Simultan (Uji F)

\begin{tabular}{|llllll|}
\hline ANOVA $^{\mathrm{a}}$ & \multicolumn{7}{c|}{ Sum of } & Mean & \\
Model & Squares & df & Square & $\mathrm{F}$ & Sig. \\
1 Regression & 1.802 & 5 & .360 & 1.555 & $.193^{\mathrm{b}}$ \\
$\quad$ Residual & 10.198 & 44 & .232 & & \\
$\quad$ Total & 12.000 & 49 & & \\
$\begin{array}{l}\text { a. Dependent Variabel: Loyalitas pelanggan } \\
\text { b. Predictors: (Constant), empaty, }\end{array}$ \\
responsivess, reabelity, assurance \\
\hline
\end{tabular}

Uji F statistik bertujuan untuk menguji hipotesis pertama, apakah variabel independen yaitu Keandalan (X1), Daya Tanggap (X2), Jaminan (X3), Empati (X4), dan Bukti Fisik (X5) mampu mempengaruhi variabel dependen yaitu Loyalitas Konsumen (Y) secara signifikan atau tidak.

Tabel 10. Analisis Uji Parsial (t Hitung)

\begin{tabular}{|c|c|c|c|c|c|}
\hline \multicolumn{6}{|l|}{ Coefficients $^{\mathrm{a}}$} \\
\hline & \multicolumn{2}{|c|}{$\begin{array}{l}\text { Unstandardiz } \\
\text { ed } \\
\text { Coefficients }\end{array}$} & $\begin{array}{l}\text { Standa } \\
\text { rdized } \\
\text { Coeffic } \\
\text { ients }\end{array}$ & $\mathrm{t}$ & Sig. \\
\hline Model & B & $\begin{array}{l}\text { Std. } \\
\text { Error }\end{array}$ & \multicolumn{3}{|l|}{ Beta } \\
\hline \multirow{4}{*}{$\begin{array}{l}1 \text { (Constant) } \\
\text { tangibles } \\
\text { reabelity } \\
\text { responsiv }\end{array}$} & 2.268 & 1.561 & & 1.453 & .153 \\
\hline & -.116 & .140 & -.126 & -.825 & .414 \\
\hline & .359 & .159 & .336 & 2.253 & .029 \\
\hline & .244 & .164 & .228 & 1.486 & .144 \\
\hline \multicolumn{6}{|l|}{ ess } \\
\hline assurance & -.074 & .116 & -.102 & -.643 & .524 \\
\hline empaty & .077 & .197 & .057 & .392 & 697 \\
\hline \multicolumn{6}{|c|}{ a. Dependent Variabel: Loyalitas pelanggan } \\
\hline
\end{tabular}

Tujuan analisis ini adalah untuk menghitung hubungan masing-masing variabel independen terhadap variabel dependen secara murni, jika variabel bebas yang lain dianggap konstan.

Pengujian hipotesis ini mengunakan (a) sebesar 0,05. Dari hasil analisis yang telah di temukan sebelumnya, maka berikut ini dapat dejelaskan nilai persamaan regresinya yaitu ; Y $=2.268+-0,116 \mathrm{X} 1+0,359 \mathrm{X} 2+$ $0,244 \mathrm{X} 3+-0,074 \mathrm{X} 4+0,071 \mathrm{X} 5$

Nilai dari koefisien regresi variabel reabelity, responsivess dan empaty adalah positif, artinya nilai reabelity, responsivess, empaty meningkat maka akan mendorong meningkatnya loyalitas pelanggan pada TRAC. Analisis korelasi dan determinasi menunjukkan bahwa nilai koefisien korelasi (R) sebesar 0,388 berarti dapat dilihat adanya hubungan yang kuat antara variabel tangible, reabelity, responsivess, assurance dan empaty terhadap loyalitas konsumen. Sedangkan nilai koefisien determinasi (R2) sebesar 0,250 variabel tangible, reabelity, responsivess, assurance dan empaty dapat menjelaskan variasi perubahan variabel loyalitas pelanggan $(\mathrm{Y})$ sebesar $25 \%$ sedangkan sisanya dijelaskan dengan variabel lain ( tabel 8 ). 
Analisis uji simultan (Uji F) menunjukkan tingkat $\mathrm{a}=$ $5 \%$ diperoleh 0,193 . Nilai ini lebih besar dari 5\% dengan demikian berarti hipotesis pertama yaitu kualitas layanan yang terdiri dari bukti fisik (X1), kehandalan (X2), daya tanggap (X3), jaminan (X4), dan empati (X5) tidak berpengaruh signifikan terhadap loyalitas konsumen(Y). Kemudian untuk mengetahui pengaruh dari masing-masing variabel independent bukti fisik (X1), kehandalan (X2), daya tanggap (X3), jaminan (X4), dan empati (X5) terhadap variabel dependent loyalitas pelanggan (Y) secara parsial, maka di uji dengan t. Uji t dilakukan dengan membandingkan nilai t Hitung dengan t Tabel (tabel 9).

Untuk mengitung hubungan masing-masing variabel independent terhadap variabel dependent secara murni, jika variabel bebas yang lain dianggap konstan maka hasil pengolahan data SPSS diperoleh hasil bahwa variabel bukti fisik (X1), kehandalan (X2), daya tanggap (X3), jaminan (X4), dan empati (X5) dengan mengunakan $a=5 \%$ nilai signifikan lebih besar dari nilai a. artinya ke empat variabel bukti fisik (X1) daya tanggap (X3), jaminan (X4), dan empati (X5) tidak berpengaruh sigifikan.

Diantara 5 variabel kualitas pelayanan terdapat 4 variabel yang tidak berpengaruh signifikan, hasil analisis data penelitian menunjukkan bahwa bukti fisik (X1) tidak berpengaruh signifikan terhadap loyalitas konsumen TRAC datang kembali atau tidak, tidak dipengaruhi oleh penampilan petugas, kenyamanan tempat, kemudahan dalam proses pelayanan, kedisiplinan petugas, kemudahan akses pelanggan dan pengunaann alat bantu dalam memberikan pelayanan tidak mampu membuat konsumen loyal. Daya tanggap (X3) tidak berpengaruh signifikan terhadap loyalitas konsumen TRAC datang kembali atau tidak, tidak dipengaruhi oleh kesigapan pegawai TRAC dalam memberikan pelayanan. Demikian juga cepat tanggap dalam menangani keluhan tidak mampu membuat konsumen loyal. Jaminan (X4) tidak berpengaruh signifikan terhadap loyalitas konsumen TRAC datang kembali atau tidak, tidak dipengaruhi oleh keramahan dan kesopanan para pegawai TRAC. Demikian juga legalitas dalam pelayanan tidak mampu membuat konsumen loyal. Empati (X5) tidak berpengaruh signifikan terhadap loyalitas konsumen TRAC datang kembali atau tidak, tidak dipengaruhi oleh sikap pegawai yang menghargai setiap pelanggan. Demikian juga sikap pegawai TRAC yang mendahulukan kepentingan pelanggan tidak mampu membuat konsumen loyal. Sedangkan kehandalan (X2) berpengaruh sangat signifikan terhadap loyalitas konsumen. Hal ini di buktikan dengan kemampuan dan kehandalan TRAC untuk menyediakan pelayanan yang terpercaya. Sehingga membuat konsumen puas dan loyal terhadap perusahaan. kemampuan dan kehandalan TRAC untuk menyediakan pelayanan yang terpercaya disini ialah pelayanan yang sesuai dengan janji yang ditawarkan TRAC pada perusahan dimana dilakukan ketika tender.
Adapun indikator yang ditawarkan ialah kecermatan, ketepatan, penyajian kendaraan (konsisi mobil layak pakai), dan memiliki standart operasional yang jelas dan dapat terpenuhi oleh pihak TRAC. Dalam kondisi ini variabel kehandalan (X2) sangat berpengaruh signifikan terhadap konsumen untuk kembali mengunakan jasa TRAC.

Sebagai rekomendasi 4 variabel yang tidak signifikan dalam membuat konsumen loyal TRAC melakukan peningkatan pada varabel-variabel Bukti Fisik (X1), Daya Tanggap (X3), Jaminan (X4), dan Empati (X5). Bukti fisik (X1) TRAC dapat meningkatkan kedisiplinan yang tinggi serta melakukan renovasi infrastruktur untuk membuat konsumen nyaman dengan keadaan dan fasilitas kantor yang diberikan saat mengunjungi perusahaan. Dalam variabel ketanggapan (X3) langkah yang dapat diambil TRAC adalah memasang sebuah notifikasi dimana notifikasi itu akan langsung masuk ke departemen $\mathrm{HO}$ ketika ada sebuah telpon dari konsumen yang tidak dapat tanggapan dari staff petugas jaga malam (keluhan 24 jam), dan ini membuktikan adanya peningkatan pada variabel ketanggapan untuk mengatasi variabel yang tidak signifikan (X3). Dalam kondisi ini TRAC juga sudah mulai mengunakan sensor getaran yang dipasang disetiap kendaraan dimana sebagai peningkaan layanan yang dapat mengetahui kecepatan pengemudi ketika mengantar konsumen. Selanjutnya TRAC memberikan jaminan(X4) keselamatan dalam bentuk kontrol pengemudi untuk menghindari kecelakaan yang diakibatkan kecepatan mobil yang tinggi tanpa kontrol. Sedangkan untuk variabel empati (X5) TRAC sudah memberikan waktu batas maksimal dalam menangani pelayanan agar dapat memberikan kenyaman pada konsumen.

\section{KESIMPULAN}

Berdasarkan hasil analisis dan pembahasan yang telah dikemukakan maka dapat diambil kesimpulan dari tujuan evaluasi penelitian pengaruh kualitas layanan terhadap loyalitas pelanggan bahwa variabel yang sangat berpengaruh signifikan ialah variabel kehandalan X2 (reabelity) hal ini dikarenakan nilai betha variabel Bukti Fisik (X1), Daya Tanggap (X3), Jaminan (X4), dan Empati (X5) menunjukkan angka paling kecil dan pengaruhnya tidak signifikan. Dalam kondisi ini TRAC harus melakukan terobosan-terobosan baru untuk memperkuat strategi dalam tahap mempertahankan dan menjadikan konsumen loyal.

\section{SARAN}

Saran terahir untuk peneliti selanjutnya ialah dapat megembangkan penelitian ini dengan meneliti faktor lain yang dapat mempengaruhi loyalitas pelanggan, misalnya faktor transaction, relationship, parthership, dan ownership. Peneliti selanjutnya juga dapat mengunakan 
metode lain dalam meneliti loyalitas pelanggan, misalnya melalui wawancara mendalam terhadap pelanggan, sehingga informasi yang didapatkan lebih bervariasi dibandingkan angket atau kuisioner yang jawabanya telah tersedia. Sehingga kedepanya saran untuk perusahaan dapat lebih memperhatikan aspek-aspek yang menjadikan pelanggan tidak signifikan loyal terhadap perusahaan.

\section{DAFTAR PUSTAKA}

Ariff, M. S. M. et al. 2014. 'The impacts of e-service quality and e-customer satisfaction on e-customer loyalty in internet banking', Advanced Science Letters. Elsevier B.V., 20(1), pp. 285-289. doi: 10.1166/asl.2014.5260.

Ariffin, H. F., Abdullah, R. P. S. R. and Bibon, M. F. 2012. 'Assessing Service Quality: Prayer's Perspective', Procedia - Social and Behavioral Sciences, 36(June 2011), pp. 511-519. doi: 10.1016/j.sbspro.2012.03.056.

Fajar Kusumo Putro, R. 2009. 'Pengaruh Kualitas Pelayanan Terhadap Loyalitas Pelanggan dengan Kepuasan Pelanggan Sebagai Variabel Pemediasi ( Studi pada Pelanggan)', Ekonomi Manajemen.

George, D. K. and Xia, C. H. 2011. 'Fleet-sizing and service availability for a vehicle rental system via closed queueing networks', European Journal of Operational Research. Elsevier B.V., 211(1), pp. 198-207. doi: 10.1016/j.ejor.2010.12.015.

Kranias, A. and Bourlessa, M. 2013. 'Investigating the Relationship Between Service Quality and Loyalty in Greek Banking Sector', Procedia Economics and Finance. Elsevier B.V., 5(13), pp. 453-458. doi: 10.1016/S2212-5671(13)00053-1.

Monjelat, N. et al. 2018. 'Pengaruh Bauran Pemasaran Terhadap Loyalitas Pengguna Oppo Smartphone The Influence Of The Marketing Mix To The Loyalty Of Oppo Smartphone Users', Director, 15(2), pp. 2017-2019. doi: 10.22201/fq.18708404e.2004.3.66178.

Rasheed, F. A. and Abadi, M. F. 2014. 'Impact of Service Quality, Trust and Perceived Value on Customer Loyalty in Malaysia Services Industries', Procedia - Social and Behavioral Sciences. Elsevier B.V., 164(August), pp. 298-304. doi: 10.1016/j.sbspro.2014.11.080.

Sari, mitha destika. 2014. 'pengaruh kualitas layanan terhadap loyalitas konsumen cafe d'puncak di samarinda'.

Yeo, G. T., Thai, V. V. and Roh, S. Y. 2015. 'An Analysis of Port Service Quality and Customer Satisfaction: The Case of Korean Container Ports', Asian Journal of Shipping and Logistics. Elsevier B.V., 31(4), pp. 437-447. doi: 10.1016/j.ajsl.2016.01.002.

Zakaria, I. et al. 2014. 'The Relationship between Loyalty Program, Customer Satisfaction and Customer Loyalty in Retail Industry: A Case Study', Procedia - Social and Behavioral Sciences. Elsevier B.V., 129, pp. 23-30. doi: 10.1016/j.sbspro.2014.03.643. 